Emperor of Liberty 
The Lewis Walpole Series in Eighteenth-Century Culture and History

The Lewis Walpole Series, published by Yale University Press with the aid of the Annie Burr Lewis Fund, is dedicated to the culture and history of the long eighteenth century (from the Glorious Revolution to the accession of Queen Victoria). It welcomes work in a variety of fields, including literature and history, the visual arts, political philosophy, music, legal history, and the history of science. In addition to original scholarly work, the series publishes new editions and translations of writing from the period, as well as reprints of major books that are currently unavailable. Though the majority of books in the series will probably concentrate on Great Britain and the Continent, the range of our geographical interests is as wide as Horace Walpole's. 


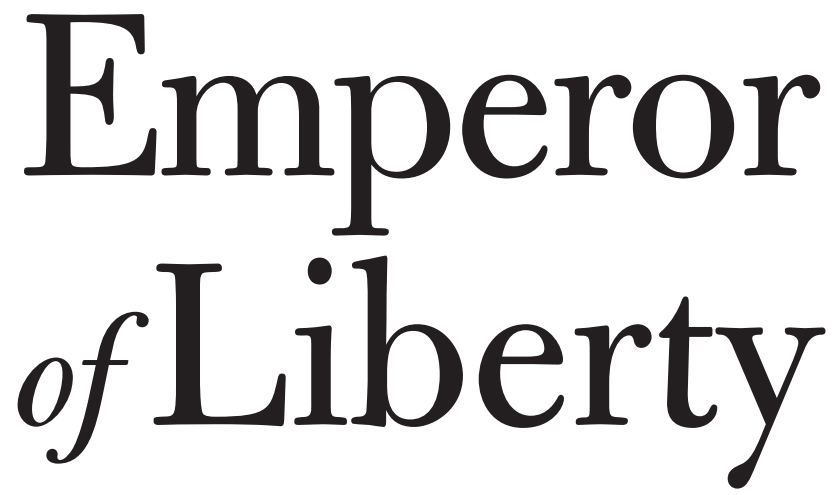

\title{
Thomas Jefferson's Foreign Policy
}

\section{Francis D. Cogliano}

\author{
Yale
}


Published with assistance from the Annie Burr Lewis Fund.

Copyright (C) 2014 by Yale University.

All rights reserved.

This book may not be reproduced, in whole or in part, including illustrations, in any form (beyond that copying permitted by Sections 107 and 108 of the U.S. Copyright Law and except by reviewers for the public press), without written permission from the publishers.

Yale University Press books may be purchased in quantity for educational, business, or promotional use. For information, please e-mail sales.press@yale.edu (U.S. office) or sales@yaleup.co.uk (U.K. office).

Designed by Sonia Shannon.

Set in Bulmer type by Westchester Book Group.

Printed in the United States of America.

Library of Congress Cataloging-in-Publication Data

Cogliano, Francis D.

Emperor of liberty : Thomas Jefferson's foreign policy / Francis D. Cogliano. pages $\mathrm{cm}$-(The Lewis Walpole series in eighteenth-century culture and history)

Includes bibliographical references and index.

ISBN 978-0-300-17993-4 (cloth : alk. paper) 1. United States-Foreign relations1801-1809. 2. Jefferson, Thomas, 1743-1826. I. Title.

$$
\begin{gathered}
\text { E331.C67 } 2014 \\
327.73009 ' 034-\mathrm{dc} 23 \\
2013049557
\end{gathered}
$$

A catalogue record for this book is available from the British Library.

This paper meets the requirements of ANSI/NISO Z39.48-1992 (Permanence of Paper).

$$
109 \begin{array}{llllllll}
10 & 7 & 6 & 5 & 4 & 3 & 2 & 1
\end{array}
$$


For Peter Onuf 
This page intentionally left blank 